\title{
Activity-guided Screening of Anti-inflammatory Compounds from the Hexane Extracts of Schisandra chinensis Fruit
}

\author{
Hee Jung Choi ${ }^{+}$, Young-Whan $\mathrm{Choi}^{2^{+}}$, Sun-Yong Baek', Bong-Seon Kim', Soon Cheol Ahn ${ }^{3}$, \\ Moon-Soo Rhee and Sik Yoon * \\ ${ }^{1}$ Department of Anatomy, School of Medicine, Pusan National University, Yangsan 626-870, Korea \\ ${ }^{2}$ Department of Horticultural Bioscience, College of Natural Resources and Life Science, Pusan National University, Miryang 627-706, Korea \\ ${ }^{3}$ Department of Microbiology and Immunology, School of Medicine, Pusan National University, Yangsan 626-870, Korea \\ ${ }^{4}$ Korea Research Institute of Bioscience \& Biotechnology, Dagieon, Korea
}

Received January 4, 2012 /Revised February 21, 2012 /Accepted February 22, 2012

\begin{abstract}
Schisandra chinensis containing a variety of pharmacologically active lignans has been traditionally used in oriental medicine. In this study, anti-inflammatory compounds were screened from the hexane extracts of $S$. chinensis by activity-guided fractionation. First, we investigated the regulatory effects on the expression of E-selectin, intercellular adhesion molecule-1 (ICAM-1) and vascular cell adhesion molecule-1 (VCAM-1) with 38 fractions from the hexane extracts of $S$. chinensis in human umbilical vein endothelial cells (HUVECs). As a result, SCKH1 among the 38 fractions from the hexane extract of $S$. chinensis was selected for further analysis based on its unique regulatory effect on cell adhesion molecules, especially on VCAM-1, in LPS-stimulated HUVECs. The subsequent activity-guided fractionation of SCKH1 resulted in the purification of SCKH1PAIBPB, which was found to suppress the expression of VCAM-1, MCP-1, IL-6 and IL-8 in HUVECs stimulated with LPS, and to inhibit the adhesive capacity between HUVECs and monocytes. Taken together, our data indicate that SCKH1PAIBPB can be proposed as an effective anti-inflammatory compound that may have a potential therapeutic use for the prevention and treatment of various inflammatory diseases as well as ischemic vascular diseases.
\end{abstract}

Key words : Activity-guided isolation, anti-inflammatory, cell adhesion molecule, Schisandra chinensis, SCKH1PAIBPB

\section{서 론}

한국사회 식생활의 서구화는 비만과 더불어 허혈성질환의 발병률을 더욱 높이고 있으며, 의료기술의 발전으로 생명이 연장되어 고령화 사회로 접어들면서 허혈성 질환에 고통을 받는 인구가 더욱더 증가하고 있다. 지난 10 년간 허혈성질환 의 사망률은 인구 10 만 명당 1999년 18.4명에서 2009년 26.0명 으로 지속적인 증가추세에 있다[24]. 현재까지 알려진 바에 의 하면 허혈성질환의 발생은 대사성질환인 당뇨, 비만, 고지혈 증과 고혈압 등의 발생 증가 및 유전자 발현이상과 관련성이 있으며, 이러한 관련성을 밝히는 연구가 최근의 주목 받는 연 구 방향이 되면서 허혈성질환 발생과 관련이 있는 많은 유전 자들이 알려지게 되었다. 최근 혈중 콜레스테롤 농도를 조절 하는 유전자인 Apolipoprotein E와 저밀도지단백콜레스테롤

\section{*Corresponding author}

Tel : +82-51-510-8044, Fax : +82-51-510-8049

E-mail : sikyoon@pusan.ac.kr

This is an Open-Access article distributed under the terms of the Creative Commons Attribution Non-Commercial License (http://creativecommons.org/licenses/by-nc/3.0) which permits unrestricted non-commercial use, distribution, and reproduction in any medium, provided the original work is properly cited. (low-density lipoprotein cholesterol, LDL)수용체가 허혈성질 환 발생과 밀접하게 관련되어 있음이 밝혀졌으나[8], 이들 인 자들에 의한 혈관 폐쇄 기전은 잘 알려져 있지 않으며, 혈액순 환 장애는 단일인자 보다는 복합적 요인에 의하여 발생할 가 능성이 훨씬 더 높을 것으로 여겨지고 있다.

현재 허혈성 조직손상의 치료는 주로 막힌 혈관의 재소통이 나 혈관재생에 초점이 맞추어지고 있다. 최근 동맥성형술이나 동맥우회로수술 같은 혈류 재개통술의 눈부신 발전에 힘입어 혈관질환의 치료 범위가 확대된 것이 사실이나, 이러한 시도 는 혈관 내피세포층의 손상을 야기시키고, 손상된 내피세포 부위에서 염증반응과 혈액응고가 유발될 수 있다. 또한 이러 한 염증반응과 혈액응고에 의하여 발생하는 혈관내 신생혈관 내막(neointima)과 혈전의 형성은 환자의 예후를 더욱 더 악화 시킬 수 있다. 따라서 새로운 치료법 개발이 절실히 요구되고 있다. 특히, 천연물을 이용한, 허혈성질환에 대한 효과적이면 서도 실용적인, 치료법 개발은 21세기 생명과학 및 생명공학 시대에 있어서 고부가가치 산업으로 등장할 것이 확실시 되고 있는 현 시점에서 약용작물을 기초로 한 허혈성질환을 예방 혹은 치료하기 위한 신물질의 발굴과 개발은 매우 중요하다.

오미자(Schizandra chinensis Baillon)는 우리나라를 비롯한 
중국, 일본 등의 여러 나라에서 약용식물로 사용되고 있으며, 예로부터 한방에서 진정, 진해, 해열제 등으로 이용되었으며, 면역조절, 항암, 항종양, 중추신경 기능강화, 혈액순환 개선, 혈압강하 작용, 간기능 복구효과, 항당뇨 등 다양한 생리활성 을 가지는 것으로 보고되어 있다[2, 9, 14, 18, 19]. 오미자는 주성분이 리그난(lignan) 화합물이며 palmitic acid와 stearic acid 등의 지방산과 유기산 등을 함유하고 있으며[10], schizandrin, schizadran, $\gamma$-schizadrin, ethamigrenal, gomisin류 등의 성분이 보고된 바 있다[12]. 오미자의 다양한 기능성에 관한 연구로서, 오미자에서 높은 함량을 보인 페놀 화합물은 항산화 활성, 항암, 항바이러스, 항염증 및 혈관보호 기능이 우수하여 다양한 생리활성을 나타내며, 그람 양성균과 그람음 성균에 대하여 우수한 항균활성을 가진다는 사실이 밝혀졌다 $[2,4,7,11,14]$. 이러한 다양한 생리활성을 가지는 오미자에 대한 본 연구자들의 최근 연구[15]에서 오미자의 hexane, chloroform과 methanol 추출물에 대한 호중구의 세포 내 칼슘 농도 변화를 관찰한 결과, chloroform과 methanol 추출물에서 는 특별한 변화가 관찰되지 않았으나, hexane 추출물은 칼슘 농도의 증가를 유도한다는 의미 있는 결과를 얻을 수 있었다. 이와 같은 사실은 오미자의 hexane 추출물이 면역세포에 특이 적인 활성을 나타낼 수 있다는 사실을 시사해준다.

따라서 본 연구에서는 약용 및 식용으로 사용되는 오미자의 분획물에서 활성분획추적법에 의해 활성 성분을 분리하고, 혈 관내피세포 증식, 생존 조절 및 항염증 효과를 검증함으로써, 허혈성질환의 예방 혹은 치료에 이용될 수 있는 활성분획과 효능성분을 발굴하고자 하였다.

\section{재료 및 방법}

\section{오미자로부터 활성물질의 분획화}

문경에서 재배한 오미자 열매를 동로농협으로부터 구입하
여 사용하였으며, 시료의 추출 및 분리 용매로는 특급 또는 일급의 hexane, chloroform, methyl chloride, methanol 및 acetone 등을 사용하였다. 물질의 순수분리는 open column chromatography를 사용하였으며, 분획을 확인하기 위한 thin layer chromatography (TLC)는 TLC silica gel $60 \mathrm{~F}_{254}(20 \times 20$ $\mathrm{cm}$, Merk)를 사용하였다.

오미자 분획물에 의한 혈관내피세포의 증식조절효과 분석

오미자 hexane 추출물이 사람배꼽정맥내피세포(human umbilical vein endothelial cells, HUVECs, Lonza, Walkersville, $\mathrm{MD}, \mathrm{USA}$ )의 증식률에 미치는 효과를 분석하 기 위해서, $\mathrm{HUVEC}$ 에 오미자 분획물을 $50 \mu \mathrm{g} / \mathrm{ml}$ 의 농도로 처리 후 24시간 또는 48시간 배양하여 WST-1 assay[6]를 실 시하였다.

오미자 분획물에 의한 혈관내피세포의 생존조절효과 분석

오미자 hexane 추출물이 HUVEC의 생존률에 미치는 효과 를 분석하기 위해, HUVEC을 혈청이 포함되지 않은 배지로 교환하여 $1 \mathrm{\mu g} / \mathrm{ml}$ 의 지질다당류(lipopolysaccharide, LPS)와 오미자 분획물을 $50 \mathrm{\mu g} / \mathrm{ml}$ 의 농도로 처리하고 24 시간 배양하 였다. 24시간 후 WST-1 assay로 세포의 생존률을 측정하였다.

LPS로 자극한 혈관내피세포에서 오미자 분획물의 세포부 착분자 및 사이토카인 mRNA 발현 조절 효과

LPS로 자극한 HUVEC에서 세포부착분자(cell adhesion molecule)의 발현을 감소시키는 오미자 hexane 추출물을 찾 기 위하여, HUVEC에 LPS $(200 \mathrm{ng} / \mathrm{ml})$ 처리 2시간 전에 오미 자 분획물을 6시간 처리한 다음, RT-PCR을 이용하여 염증반 응의 매우 중요한 매개인자이며 대표적인 세포부착분자인 intracellular adhesion molecule-1 (ICAM-1) 및 vascular cell adhesion molecule-1 (VCAM-1)의 발현수준을 조사하였다.

Table 1. Primer pairs used RT-PCR

\begin{tabular}{|c|c|c|c|}
\hline Target gene & GeneBank accession nos. & Sequences of primer & Product size \\
\hline E-selectin & BC142677 & $\begin{array}{l}\text { S: } \text { 5'-ACCTCCACGGAAGCTATGAC-3' }^{\prime} \\
\text { A : 5'-TCCCAGATGAGGTACACTGA-3' }\end{array}$ & $796 \mathrm{bp}$ \\
\hline ICAM-1 & NM000201 & $\begin{array}{l}\text { S : 5'-CTGCAGACAGTGACCATCTA-3' } \\
\text { A : 5'-AAAGTGCCATCCTTTAGACA-3' }\end{array}$ & $407 \mathrm{bp}$ \\
\hline VCAM-1 & X53051 & $\begin{array}{l}\text { S: }: 5^{\prime} \text {-GAGCTACAGCCTCTTTCTGA-3' } \\
\text { A : 5'-GAGGATGCAAAATAGAGCAC-3' }\end{array}$ & $461 \mathrm{bp}$ \\
\hline MCP-1 & X14768 & $\begin{array}{l}\text { S: }: 5^{\prime} \text {-TCTCAGTGCAGAGGCTCGCGA-3' } \\
\text { A : 5'-GAGTGAGTGTTCAAGTCTTCG-3' }\end{array}$ & $183 \mathrm{bp}$ \\
\hline IL-6 & M14584 & $\begin{array}{l}\text { S: }: 5^{\prime} \text {-CCTTCCAAAGATGGCTGAA-3' } \\
\text { A : 5'-CAGGGGTGGTTATTGCATCT-3' }\end{array}$ & $230 \mathrm{bp}$ \\
\hline IL-8 & BC013615 & $\begin{array}{l}\text { S : 5'-ATGACTTCCAAGCTGGCCGTGGCT-3' } \\
\text { A : 5'-TCTCAGCCCTCTTCAAAAACTTCTC-3' }\end{array}$ & $292 \mathrm{bp}$ \\
\hline GAPDH & NM002046 & $\begin{array}{l}\text { S : 5'-AAGTTGGATATTGTTGCCATC-3' } \\
\text { A : 5'-ACTGTGGTCATGAGTCCTTC-3' }\end{array}$ & $454 \mathrm{bp}$ \\
\hline
\end{tabular}


그리고 SCKH1 분획으로부터 분리한 SCKH1PAIBPB를 $25 \mu \mathrm{g}$ $/ \mathrm{ml}$ 의 농도로 처리한 다음 염증성 사이토카인인 interleukin-6 (IL-6), interleukin-8 (IL-8), monocyte chemoattractant protein-1 (MCP-1)의 유전자를 증폭하기 위해 각각 의 primer를 제작하여 사용하였다(Table 1). PCR 반응 조건은 cycle 시작 전 $94^{\circ} \mathrm{C}$ 에서 5 분간 가열 한 뒤 매 cycle 마다 $94^{\circ} \mathrm{C}$ 에 서 30 초 간 denaturation 시키고, $57^{\circ} \mathrm{C}$ 에서 30 초 동안 annealing 한 뒤 $72^{\circ} \mathrm{C}$ 에서 30 초 동안 extension하는 과정을 28 회 반복
하였고 cycle 종료 후 $72^{\circ} \mathrm{C}$ 에서 10 분 동안 생성된 가닥을 extension하는 과정을 거쳤다. PCR 반응이 끝난 후에는 중폭된 유전자를 $1.5 \%$ agarose gel을 이용하여 전기영동 후 ethidium bromide로 염색하여 유전자를 확인하였다.

\section{혈관내피세포와 단핵구 사이의 부착능 측정}

HUVEC에 SCKH1PAIBPB를 $25 \mu \mathrm{g} / \mathrm{ml}$ 의 농도로 처리한 후 6시간이 경과되었을 때 LPS $(200 \mathrm{ng} / \mathrm{ml})$ 를 처리하고 단핵

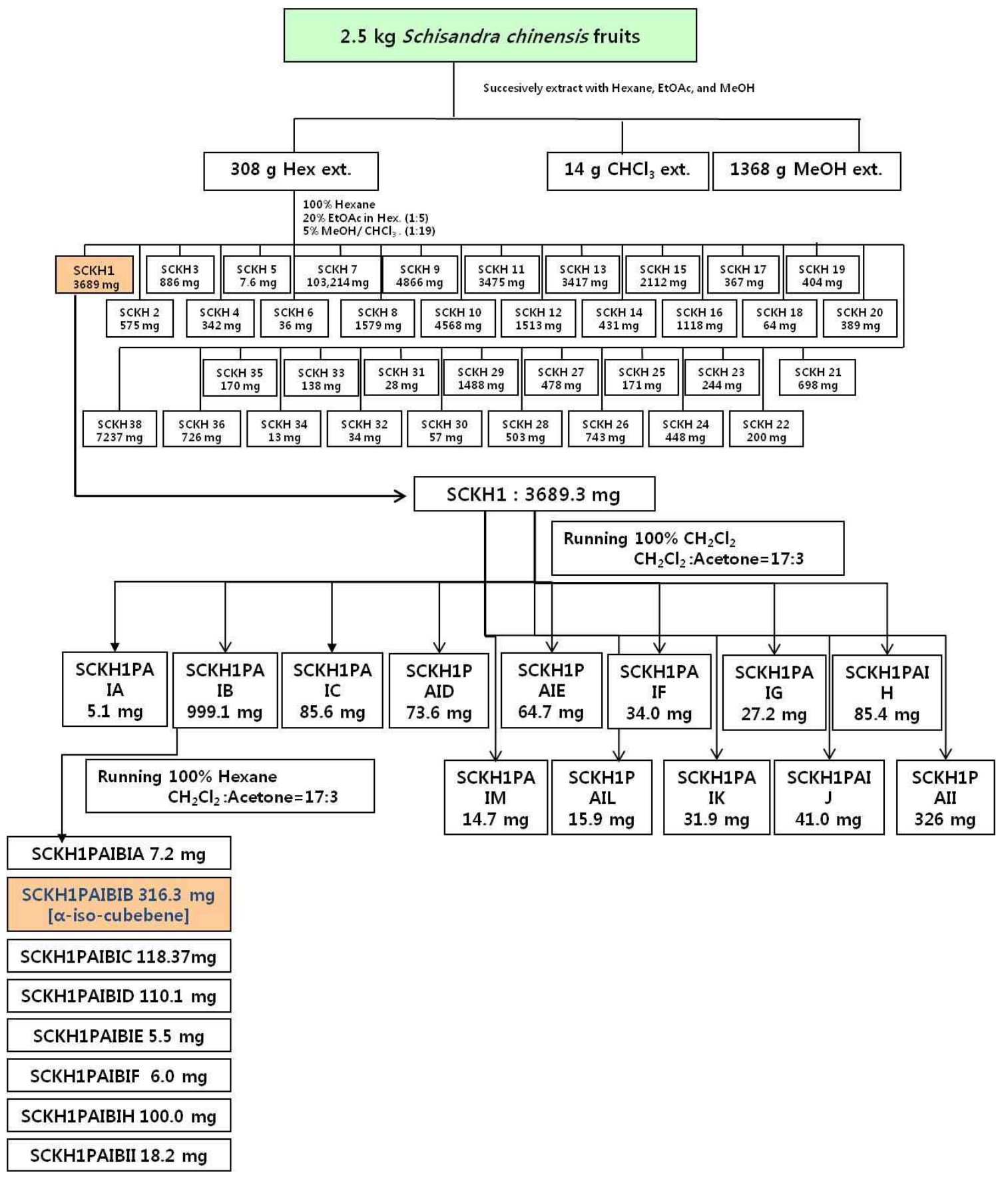

Fig. 1. Isolation scheme of activity-guided isolation of anti-inflammatory fractions from Schisandra chinensis. 
구와 반응시켰다. 그로부터 4 시간 후 혈관내피세포에 부착된 단핵구의 수를 산정하였다.

\section{통계처리}

실험결과의 통계학적 처리는 Student's t-tests를 사용하였 으며, $p<0.05$ 수준 이하에서 유의성을 결정하였다.

\section{결과 및 고찰}

\section{오미자 추출물로부터 항염증 물질의 분리}

건조된 오미자(Schisandra chinensis) 열매 $2.5 \mathrm{~kg}$ 을 hexane, chloroform $\left(\mathrm{CHCl}_{3}\right)$, methanol $(\mathrm{MeOH})$ 을 이용하여 상온에서 연속적으로 추출하여 hexane 추출물 $309 \mathrm{~g}, \mathrm{CHCl}_{3}$ 추출물 14 $\mathrm{g}, \mathrm{MeOH}$ 추출물 $1,368 \mathrm{~g}$ 을 얻었다. 면역학적 활성을 고려하여 [15] 이 중 활성이 높은 hexane 추출물을 대상으로 1 차 silica gel $(4 \mu \mathrm{m}$, Baker, NJ, USA) column chromatography를 하였 다. $100 \%$ hexane, ethylacetate $(\mathrm{EtOAc}) /$ hexane $(1: 4, \mathrm{v} / \mathrm{v})$, $\mathrm{MeOH} / \mathrm{CHCl} 3(1: 19, \mathrm{v} / \mathrm{v})$ 을 전개용매로 사용하여 순차적으 로 용출하여 SCKH1 SCKH38의 총 38개의 분획을 얻었다. 각각의 분획물 중 항염증 활성이 관찰된 분획물 SCKH1 $(3,689$ $\mathrm{mg}$ )을 대상으로 2차 silica gel column chromatography를 실시 하였다. $100 \% \mathrm{CHCl}_{3}$, dichlormethane $\left(\mathrm{CH}_{2} \mathrm{Cl}_{2}\right) /$ acetone $(17: 3$, $\mathrm{v} / \mathrm{v})$ 을 전개용매로 순차적으로 용출하여 SCKH1PAIA SCKH1PAIM의 총 13 개의 분획을 얻어 항염증 활성을 관찰하 였다. 활성이 검정된 SCKH1PAIB $(999.1 \mathrm{mg})$ 을 대상으로 동일 한 전개용매를 사용하여 3 차 silica gel column chromatography를 실시하고 총 8개의 SCKH1PAIBIA SCKH1PAIBII의 분획물을 얻었다(Fig. 1). 항염증 활성이 검정된 순수물질 SCKH1PAIBPB $(316.3 \mathrm{mg})$ 는 본 연구진의 다른 연구에서 a -iso-cubebene 으로 동정되었다[3](Fig. 2).

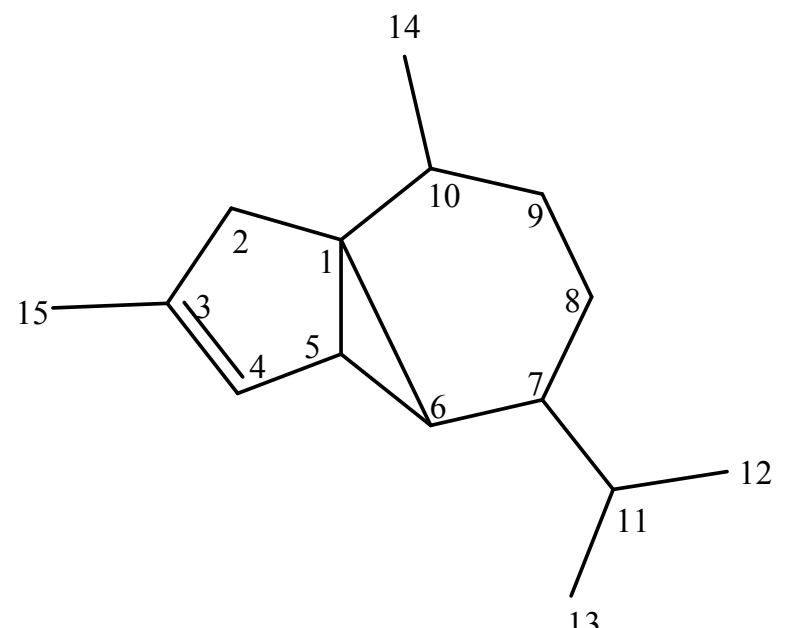

13

Fig. 2. Structure of SCKH1PAIBPB (a-iso-cubebene).
혈관내피세포에서 오미자 분획물의 세포부착분자 및 사이토 카인 유전자 발현 조절 효과

혈관에서의 염증반응의 기전으로, 조직 손상에 의한 대식 세포의 활성은 다양한 사이토카인을 분비하고 이는 혈관 내 의 VCAM-1 및 ICAM-1 등의 발현을 유도하여 단핵구나 호중 구 등을 조직으로의 이주를 촉진시킴으로써 2차적인 염증반 응을 유발하는 것으로 알려져 있다[26]. 이와 같은 세포부착 분자의 발현을 감소시키는 오미자 hexane 추출물로부터 활성 분획을 추적하기 위해 HUVEC에 LPS $(200 \mathrm{ng} / \mathrm{ml})$ 를 자극하 기 2시간 전에 오미자 분획물 $(50 \mathrm{\mu g} / \mathrm{ml})$ 을 처리하여 RT-PCR 로 확인하였다. 그 결과 오미자 분획물 중에서 $\mathrm{SCKH1}$, $\mathrm{SCKH10}$ 및 SCKH19에 의해 E-selectin의 발현이 감소되었고, SCKH1, SCKH7, SCKH9, SCKH13, SCKH17 및 SCKH19에 의해 ICAM-1의 발현이 감소되었으며 VCAM- 1 의 발현은 $\mathrm{SCKH1}$ 첨가에 의해서만 특이적으로 감소됨을 확인할 수 있 었다(Fig. 3).

\section{오미자 분획물의 혈관내피세포 증식능 조절 효과}

혈관내피세포의 증식유도효과를 분석하기 위해서 오미자 분획물 $(50 \mu \mathrm{g} / \mathrm{ml})$ 을 HUVEC에 각각 24시간 또는 48시간 처리 한 후 WST-1 assay를 이용하여 HUVEC의 증식률을 측정한 결과, 24 시간 배양군에서는 SCKH9에서 증식률의 증가를 보 였고, 48 시간 배양군에서는 SCKH7 및 SCKH9에서 증식률의 증가를 보였다(Fig. 4). 이러한 결과는 향후 SCKH7과 SCKH9 그리고 그 성분들을 이용하여 혈관내피세포의 증식을 촉진시 킴으로써 다양한 허혈성 혈관질환의 예방 및 치료에 유용한 기능성 천연식품소재 및 신약으로 활용이 가능할 것임을 시사 한다.

\section{오미자 분획물의 혈관내피세포 생존능 조절 효과}

무혈청배지에 배양 중인 HUVEC에 $1 \mu \mathrm{g} / \mathrm{ml}$ 의 LPS와 오미 자 분획물 $(50 \mu \mathrm{g} / \mathrm{ml})$ 을 24 시간 처리하여 세포의 생존율을 WST-1 assay로 측정한 결과 LPS에 의해 감소했던 생존률이 $\mathrm{SCKH7}$ 과 SCKH9를 처리한 군에서 증가하였다(Fig. 5). 이러 한 결과는 향후 SCKH7과 SCKH9 그리고 그 성분들을 이용하 여 혈관내피세포의 생존율을 증가시킴으로써 다양한 허혈성 혈관질환의 예방 및 치료에 유용한 기능성 천연식품소재 및 신약으로 활용이 가능할 것임을 시사해주는 소견이라 할 수 있다.

\section{오미자 추출물로부터 분리한 SCKH1PAIBPB의 항염증 효능 검증}

SCKH1이 혈관내피세포에서 LPS에 의해 유도된 세포부착 분자의 발현을 특이적으로 감소시킨다는 사실을 확인하였기 때문에 SCKH1으로부터 SCKH1PAIBIA, SCKH1PAIBPB, SCKH1PAIBIC 및 SCKH1PAIBID를 순수분리한 후, 그 중 가 
A

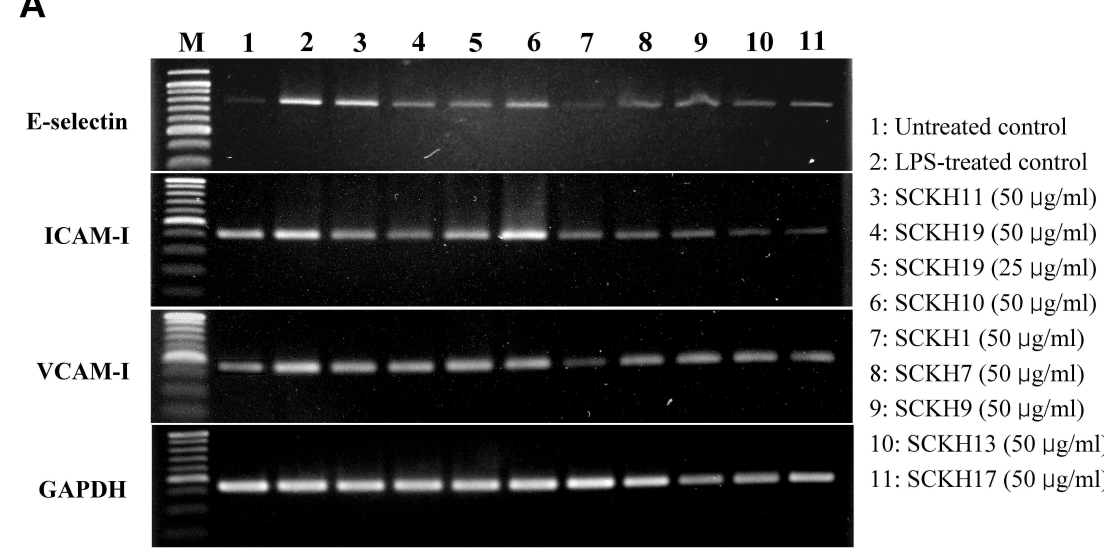

B
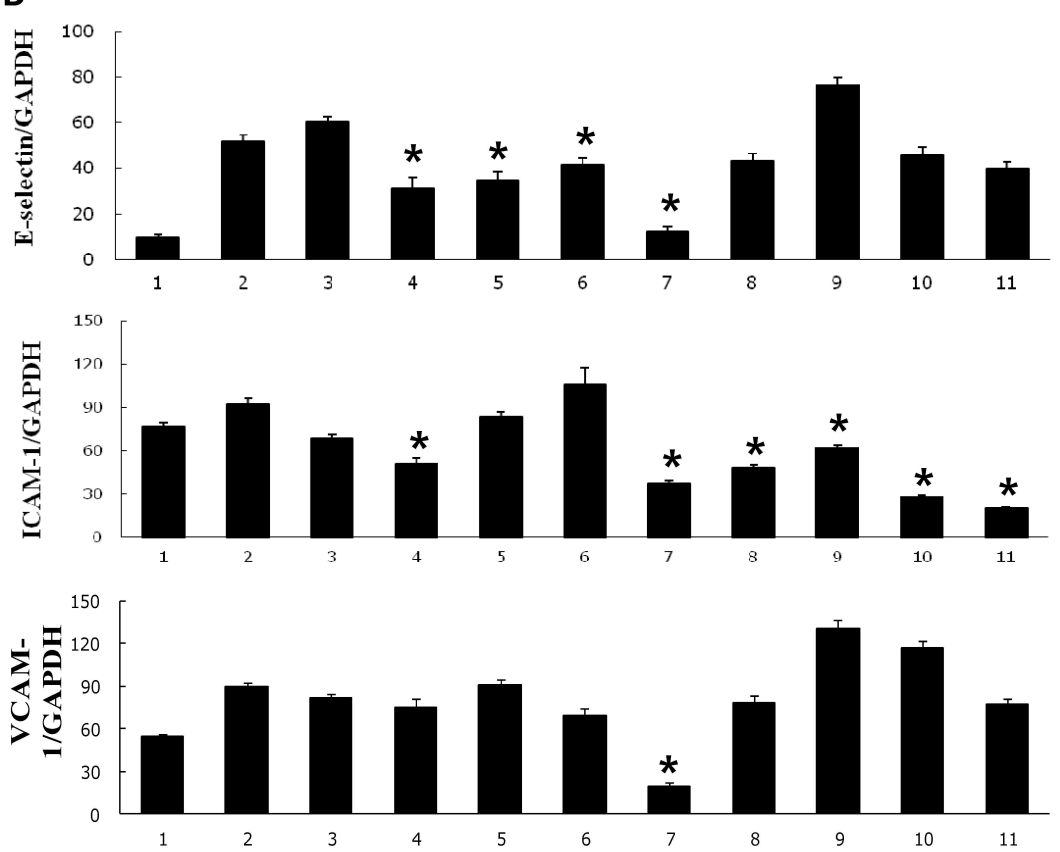

Fig. 3. The effects of hexane extracts of $S$. chinensis on major cell adhesion molecule expression in human umbilical vein endothelial cells (HUVECs) treated with LPS. HUVECs were incubated for $2 \mathrm{hr}$ after treatment with the fractions of hexane extracts of $S$. chinensis, and then followed by incubation for $6 \mathrm{hr}$ after treatment with LPS $(200 \mathrm{ng} / \mathrm{ml})$. (A) RT-PCR analysis for gene expression of E-selectin, ICAM-1, VCAM-1 and GAPDH was performed. (B) Results are ratios of E-selectin, ICAM-1 and VCAM- 1 mRNA normalized to GAPDH mRNA expressed as means \pm SD. ${ }^{*} \not<0.05$ compared with the corresponding control value as determined by t-test.

장 주된 성분인 SCKH1PAIBPB가 HUVEC에서 VCAM-1, MCP-1, IL-6 및 IL-8 유전자의 발현에 미치는 효과를 분석하였 다. 그 결과 SCKH1PAIBPB $(25 \mu \mathrm{g} / \mathrm{ml})$ 에 의해 이들 유전자의 발현이 현저하게 감소됨을 확인할 수 있었다(Fig. 6).

또한 혈관내피세포와 단핵구 사이의 부착능을 측정하기 위 해 SCKH1PAIBPB $(25 \mu \mathrm{g} / \mathrm{ml})$ 를 처리한 후 6시간이 경과되었 을 때 LPS $(200 \mathrm{ng} / \mathrm{ml})$ 를 처리하고 단핵구와 반응시켰다. 그 로부터 4 시간 후 혈관내피세포에 부착된 단핵구의 수를 산정 한 결과 LPS에 의해 증가한 혈관내피세포와 단핵구 사이의 부착능이 SCKH1PAIBPB 처리군에서 현저하게 감소하였다
(Fig. 7).

본 연구자들에 의한 추가적인 연구를 통해 SCKH1PAIBPB 는 TNF- $a$ 로 자극한 HUVEC에서 항산화효과, VCAM-1과 E-selectin의 발현 억제효과, 혈관내피세포와 단핵구 사이의 부착능 감소효과 및 NF-kB 전사인자의 활성 억제효과를 나타 내었다[3]. 또한 최근 생쥐 패혈증 모델을 이용한 연구에서 SCKH1PAIBPB는 항균작용을 증진시킬 뿐만 아니라 염증성 사이토카인의 생산, 면역세포의 자멸사 및 폐염증을 억제함으 로써 생쥐의 생존율을 현저하게 향상시킨다는 사실이 보고되 었다[16]. 


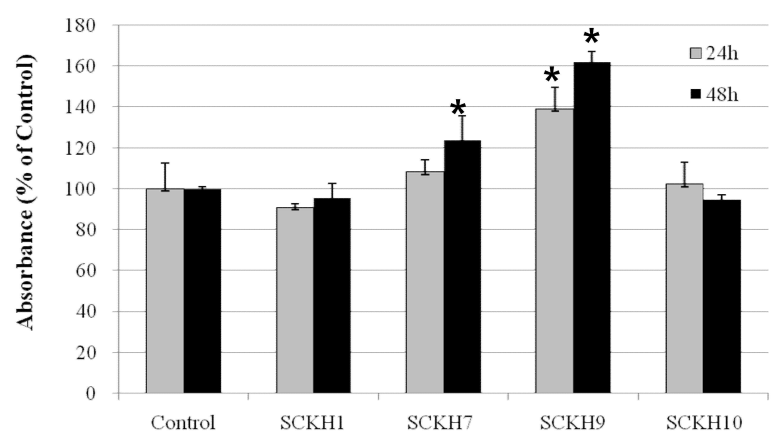

Fig. 4. Proliferation assay of $S$. chinensis extracts on HUVECs. HUVECs were incubated for $24 \mathrm{hr}$ and $48 \mathrm{hr}$ after treatment with $1 \mu \mathrm{g} / \mathrm{ml}$ LPS and $S$. chinensis hexane extracts $(50 \mu \mathrm{g} / \mathrm{ml})$. The rate of cell proliferation was assayed by WST-1 assay. Data are expressed as the mean \pm SD. ${ }^{*} p<0.05$ compared with the corresponding control value as determined by t-test.

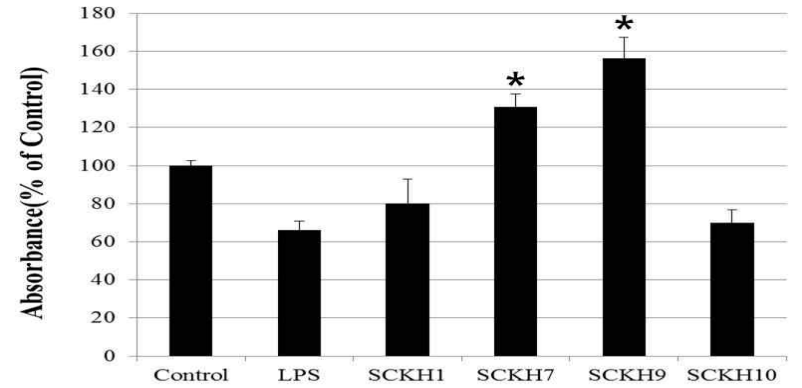

Fig. 5. Survival assay of $S$. chinensis hexane extracts on LPS-treated HUVECs. HUVECs were incubated in serum-free media for $24 \mathrm{hr}$ after treatment with $1 \mu \mathrm{g} / \mathrm{ml}$ LPS and $S$. chinensis hexane extracts $(50 \mu \mathrm{g} / \mathrm{ml})$. The degree of cell survival was assayed by WST-1 assay. Data are expressed as the mean \pm SD. * $p<0.05$ compared with the corresponding control value as determined by $\mathrm{t}$-test.
A

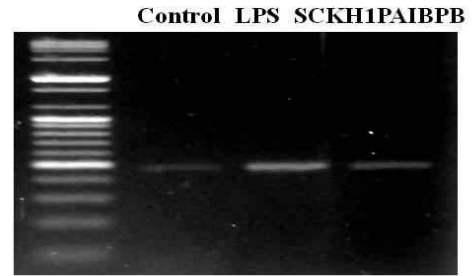

VCAM-1

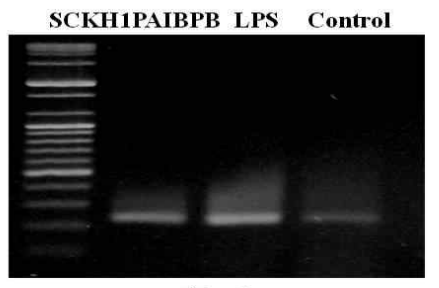

IL-6

B
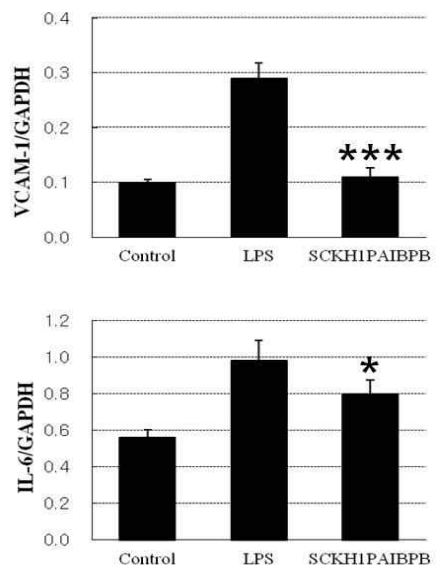

Control LPS SCKH1PAIBPB

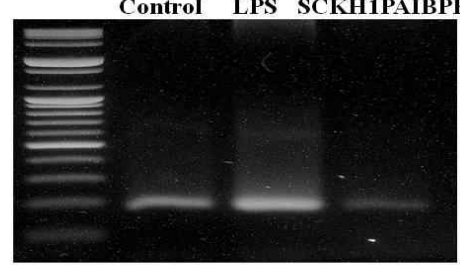

MCP-1

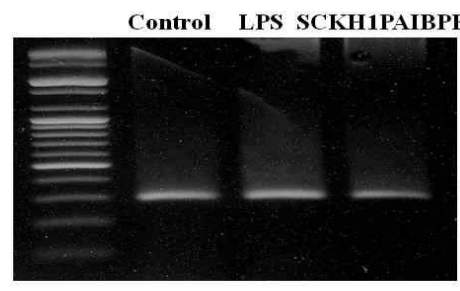

IL-8
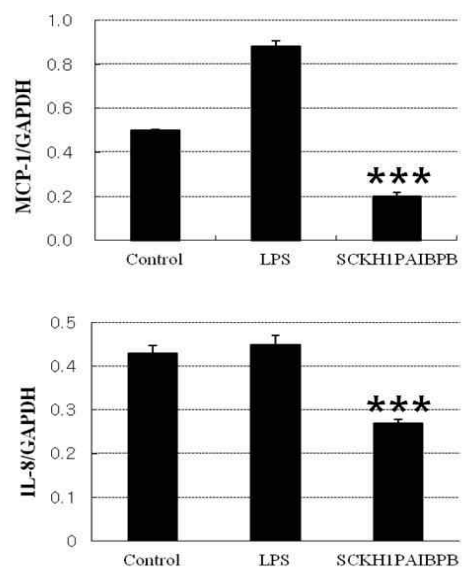

Fig. 6. The effects of SCKH1PAIBPB $(25 \mu \mathrm{g} / \mathrm{ml})$ from hexane extracts of $S$. chinensis on VCAM-1, MCP-1, IL-6 and IL-8 expression in HUVECs treated with LPS. HUVECs were incubated for $2 \mathrm{hr}$ after treatment with SCKH1PAIBPB from hexane extracts of $S$. chinensis, and then followed by incubation for $6 \mathrm{hr}$ after treatment with LPS ( $200 \mathrm{ng} / \mathrm{ml})$. (A) RT-PCR analysis for gene expression of VCAM-1, MCP-1, IL-6, IL-8 and GAPDH was performed. The density of each band was measured by a scanning densitometry. (B) Data are expressed as ratios of VCAM-1, MCP-1, IL-6 and IL-8 mRNA normalized to GAPDH mRNA and then expressed as the mean \pm SD. ${ }^{*} p<0.05,{ }^{* * *} p<0.001$ compared with the values of LPS-treated group as determined by $\mathrm{t}$-test. 


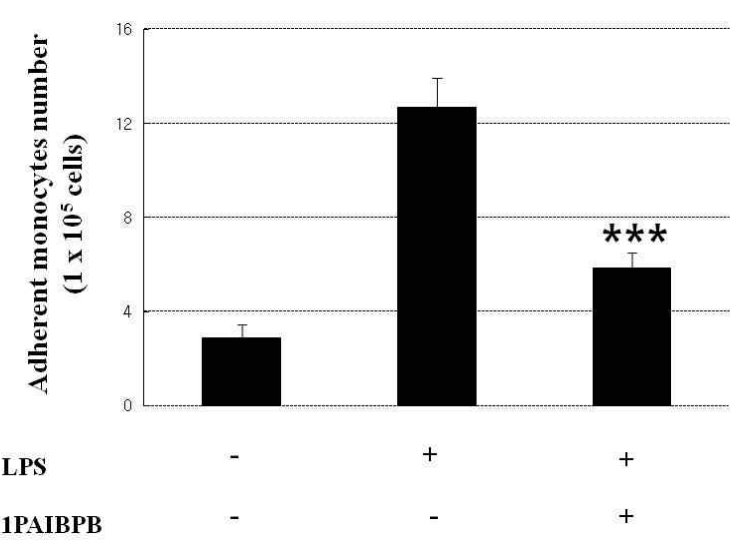

SCKH1PAIBPB

Fig. 7. The effect of SCKH1PAIBPB $(25 \mu \mathrm{g} / \mathrm{ml})$ from hexane extracts of $S$. chinensis on U937 monocyte adhesion in LPS-stimulated HUVECs. The cells were pretreated with SCKH1PAIBPB for $2 \mathrm{hr}$ followed by the LPS $(200 \mathrm{ng} / \mathrm{ml})$ for $4 \mathrm{hr}$. The number of adherent monocytes to HUVECs was determined by cell counting. Data are expressed as the mean $\pm \mathrm{SD}$. ${ }^{* *} p<0.001$ compared with the values of LPS-treated group as determined by t-test.

TNF- $a$ 와 같은 전염증성 사이토카인(pro-inflammatory cytokine)은 다양한 염증성 및 면역성 병변형성 과정에서 그 분 비가 증가되어, 혈관내피세포를 자극함으로써 인체의 다양한 염증성 및 면역성 질환을 유발한다는 사실이 잘 알려져 있다 $[5,20]$. 따라서 이러한 염증단계에 중요한 역할을 하는 염증매 개인자인 세포부착분자의 발현을 억제할 수 있는 효능을 가진 물질은 염증반응을 수반하는 병적 과정을 제어함으로서 다양 한 염증성질환 및 허혈성질환에 대한 예방 및 치료제로 개발 될 수 있을 가능성이 높다고 할 수 있다[27]. 특히 동맥경화증 과 같은 질환의 발병과정에서 필수적인 단계인 단핵구와 혈관 내피세포 사이의 상호작용은 혈관내피세포에서 세포부착인 자인 VCAM-1 등에 의해 조절되는데, 염증이 발생하게 되면 이러한 세포부착인자의 발현이 증가하게 되고, 이를 통해 단 핵구가 혈관을 통과함으로서 동맥경화증을 유발하는데 중요 한 역할을 하게 된다[13, 24]. 특히 혈관내피세포의 산화적 손 상은 혈관의 염증을 유발시키고 이를 통해 단핵구가 혈관내피 세포에서 단핵구의 부착을 촉진하는 세포부착분자의 발현이 유도되기 때문에 이러한 산화적 스트레스도 동맥경화증의 유 발에 관여한다. 따라서 TNF-a 등과 같은 전염증성인자에 의해 자극된 혈관내피세포에서 VCAM-1의 발현을 억제할 수 있는 물질 및 산화적 스트레스의 유발을 억제할 수 있는 물질의 발굴은 동맥경화증의 발생과 진행을 제어할 수 있는 새로운 치료적 접근방법을 개발하는데 큰 의의를 지닌다[21].

그러므로 $\mathrm{TNF}-a$ 와 같은 전염증성인자에 의해 산화적 스트레 스가 유발된 혈관내피세포에서 항산화효과를 가질뿐만 아니라 VCAM-1의 발현을 억제하는 효과를 가지는 SCKH1PAIBPB 는 향후 동맥경화증과 같은 허혈성 혈관질환 및 다양한 염증
성질환의 효과적인 예방 및 치료제 개발에 응용될 수 있을 것으로 사료된다.

\section{감사의 글}

이 논문은 부산대학교 자유과제 학술연구비(2년)에 의하여 연구되었음.

\section{References}

1. Choi, S. R., Kim, C. S., Kim, J. Y., You, D .H., Kim, J. M., Kim, Y. S., Song, E. J., Kim, Y. G., Ahn, Y. S. and Choi, D. G. 2011. Changes of Antioxidant activity and lignan contents in Schisandra chinensis by harvesting times. Korean J Med Crop Sci 19, 414-420.

2. Cho, Y. J., Ju, I. S., Kim, B. C., Lee, S. Kim, M. J., Lee, B. G., An, B. J., Kim, J. H. and Kwon, O. J. 2007. Biological activity of omija (Schizandra chinensis baillon) extracts. J. Kor Soc App Bio Chem 50, 198-203.

3. Choi, Y. W., Kim, H. J., Park, S. S., Chung, J. H., Lee, H. W., Oh, S. O., Kim, B. S., Kim, J. B., Chung, H. Y., Yu, B. P., Kim, C. D. and Yoon. S. 2009. Inhibition of endothelial cell adhesion by the new anti-inflammatory agent a -iso-cubebene. Vascul Pharmacol 51, 215-224.

4. Chung, K. H., Lee, S. H., Lee, Y. C. and Kim, J. T. 2001. Antimicrobial activity of Omija (Schizandra chinensis) extracts. J Korean So Food Sci Nutr 30, 127-132.

5. Dinarello, C. A. 2000. Pro-inflammatory cytokines. Chest 118, 503-508.

6. Hiroshi, S., Yasuhide, M., Masuko, K. and Tojiro, T. 1996. Effects of some vegetable extracts on the growth of human cell lines measured by the WST-1 assay. Nippon Shokuhin Kagaku Kogaku Kaishi 43, 64-68.

7. Jeon, T. W., Jo, C. H, Kim, H. and Byun, M. W. 2002. Inhibitory effect on tyrosinase and xanthine oxidase, and nitrite scavenging activities of Schizandrae fructus extract by gamma irradiation. Korean J Food Pre 9, 369-374.

8. Kang, S. Y. and Lee, W. I. 2006. Apolipoprotein E polymorphism in ischemic stroke patients with different pathogenetic origins. Korean J Lab Med 26, 210-216.

9. Kim, C. H., Kwon, M .C., Kim, H. S., Ahn, J. H., Chio, G. P., Choi, Y. B., Ko, J. R. and Lee, H. Y. 2007. Enhancement of immune activities of Kadsura Japonica dunal. Through Conventional Fermentation Process. Korean J Med Crop Sci 15, 162-169.

10. Kim, D. G., Kim, M. B., Kim, H., Park, J. H., Im, J. P. and Hong, S. H. 2005. Herb medicinal pharmacognosy. pp. 407, Shinill Books, Seoul, Korea.

11. Kim, J .S. and Choi, S. Y. 2008. Physicochemical properties and antioxidative activities of Omija (Schizandra chinensis Bailon). Korean J Food Nutr 21, 35-42.

12. Kim, O. C. and Jang, H. J. 1994. Volatile components of Schizandra chinensis Baillon. Korean J Agric Biotech 39, 30-36.

13. Lee, C. H., Yi, H. S., Kim, J. E., Heo, S. K., Cha, C. M., 
Won, C. W. and Park, S. D. 2009. Anti-oxidative and anti-inflammatory effect of fractionated extracts of Smilacis glabrae rhizoma in human umbilical vein endothelial cell. Korean $J$ Herbology 24, 39-50.

14. Lee, S. H., Lee, Y. C. and Yoon, S. K. 2003. Isolation of the antimicrobial compounds from Omija (Schizandra chinensis) extract. Korean J Food Sci Technol 35, 483-487.

15. Lee, Y. J., Shim, J. W,. Lee, Y. J., Parka, Y. H., Lee, H. Y., Kim, S. D., Choi, Y. W. and Bae, Y. S. 2009. Identification of a novel compound that stimulates intracellular calcium increase and CXCL8 production in human neutrophils from Schisandra chinensis. Biochem Biophys Res Comm 379, 928-932.

16. Lee, S. K., Kim, S. D., Lee, H. Y., Baek, S. H., Ko, M. J., Son, B. G., Park, S., Choi, Y. W. and Bae, Y. S. 2012. a-Iso-cubebene, a natural compound isolated from Schisandra chinensis fruit, has therapeutic benefit against polymicrobial sepsis. Biochem Biophys Res Comm 426, 226-231.

17. Liu, C., Zhang, S. and Wu, H. 2009 Non-thermal extraction of effective ingredients from Schisandra chinensis Baill and the antioxidant activity of its extract. Nat Prod Res 23, 1390-1401.

18. Mok, C. K. 2005. Quality characteristics of instant tea prepared from spray-dried Omija (Schizandra chinensis Baillon) extract/grape juice mixture. Food Eng Prog 9, 226-230.

19. Oh, S. L., Kim, S. S., Min, B. Y. and Chung, D. H. 1990. Composition of free sugars, free amino acid, non-volatile organic acids and tannins in the extracts of $L$. chinesis $M$., $A$. acutiloba $K, S$. chinensis $B$. and $A$. sessiliflorum S. Korean J Food Sci Technol. 22, 76-81.
20. Piguet, P. E., Grau, G. E., Houser, C. and Vassalli, P. 1991. Tumor necrosis factor is a critical mediators in hapten induced irritant and contact hypersensitivity reaction. J Exp Med 173, 673-679.

21. Rong, Y., Geng, Z. and Lau, B. H. 1996. Ginko biloba attenuates oxidative stress in macrophages and endothelial cells. Free Radic Biol Med 20, 121-127.

22. Ryu, I. H. and Kwon, T. O. 2012. The antioxidative effect and Ingredients of oil extracted from Schizandra chinensis seed. Korean J Med Crop Sci 20, 63-71.

23. Sladkovsky, R., Solich, P. and Opletal, L. 2001. Simultaneous determination of quercetin, kaempferol and (E)-cinnamic acid in vegetative organs of Schisandra chinensis Baill. by HPLC. J Pharm Biomed Anal 24, 1049-1054.

24. Statistics Korea. "Annual report on the cause of death statistics, 2009". (http://www.kostat.go.kr).

25. Stein, O, Thiery, J. and Stein, Y. 2002. Is there a genetic basis for resistance to atherosclerosis? Atherosclerosis 160, 1-10.

26. Tribolo, S., Lodi, F., Connor, C., Suri, S., Wilson, V. G., Taylor, M. A., Needs, P. W., Kroon, P. A. and Hughes, D. A. 2008. Comparative effects of quercetin and its predominant human metabolites on adhesion molecule expression in activated human vascular endothelial cells. Atherosclerosis 197, 50-56.

27. Yoon, W. Lee, J., Kim, K. N., Kim, J. Y. and Park, S. Y. 2007. In vitro Anti-inflammatory activity of the Artemisia fukudo extracts in murine macrophage RAW 264.7 cells. Korean J Food Sci Technol 39, 464-469.

\section{초록 : 생리활성분획 추적방법을 통한 오미자 추출물의 항염증 활성 분석}

최희정 ${ }^{*}$ 최영환 ${ }^{2} \cdot$ 백선용 $^{1} \cdot$ 김봉선 $^{1} \cdot$ 안순철 $^{3} \cdot$ 이문수 ${ }^{4} \cdot$ 윤 식 $^{1} \star$

(부산대학교 ${ }^{1}$ 의학전문대학원 해부학교실, ${ }^{2}$ 생명자원과학대학 원예생명과학과, ${ }^{3}$ 의학전문대학원 미생물학 및 면역학교실, ${ }^{4}$ 한국생명공학연구원 생명자원센터)

예로부터 한방이나 민간요법에서 다양한 약리효능을 가진 약제로 알려져 있는 오미자 열매로부터 항염증 활성 을 갖는 유용한 물질을 동정하고자 본 연구를 수행하였다. 먼저 오미자의 hexane 추출물로부터 38 개의 분획물을 분리한 다음 각 분획의 항염증 활성을 측정하였다. 그 결과 오미자 분획물 중 생리활성이 높은 SCKH1을 선택하 여 활성분획 추적방법을 통해 SCKH1PAIBPB을 분리하였다. SCKH1PAIBPB는 VCAM-1, MCP-1, IL-6 및 IL-8의 발현을 감소시키며, 혈관내피세포와 단핵구 사이의 부착능을 억제시킨다는 사실을 확인할 수 있었다. 따라서 본 연구를 통해 규명된 오미자 분획물 및 SCKH1PAIBPB의 항염증효과 뿐만 아니라 혈관내피세포 증식 및 생존능 촉진작용을 응용하여, 다양한 허혈성질환 뿐만 아니라 염중성질환의 예방 및 치료에 활용할 수 있을 것으로 사료 된다. 